\title{
Numerical Taxonomy of the Flexibacteria
}

\author{
By RITA R. COLWELL \\ Department of Biology, Georgetown University, Washington, D.C. 20007, U.S.A.
}

(Accepted for publication 4 June 1969)

SUMMARY

\begin{abstract}
A method of Adansonian taxonomy was applied to a set of flexuous, gliding bacteria. A clustering of strains which corresponded to Saprospira grandis, Flexibacter flexilis, Saprospira thermalis, Flexibacter giganteus and Flexibacter roseolus was observed from the computed data. High similarity values $(>80 \%)$ were found for strains assigned to the genera Cytophaga, Flexibacter and Microscilla.
\end{abstract}

\section{INTRODUCTION}

The classification of the gliding bacteria is relatively confusing. Lewin (I962), Soriano \& Lewin (1965) and Lewin (1969) have attempted to clarify the situation. The few fragmentary diagnostic schemes for the flexibacteria proposed hitherto, have relied heavily on morphological criteria for classification and identification. The work of Lewin \& Lounsbery (1969) represents a departure from the historical approach. Morphological, physiological, biochemical and nutritional characteristics were included in their analysis of nearly a hundred strains of flexibacteria.

The study reported in this paper was undertaken in order to apply the principles of Adansonian analysis and computer methods of taxonomic analysis to the problem of the classification and identification of these strains. Aside from the studies of Hayes (I 963) and Floodgate \& Hayes (1963) on strains of marine flavobacteria, some of which glide, no numerical taxonomic analysis of the taxonomic data of the flexibacteria or closely related forms has previously been attempted. The bacterial strains, isolated and characterized by Lewin \& Lounsbery (1969), represent a group of organisms capable of gliding on solid media and apparently lacking rigid cell walls, flagella and endospores. The strains studied were all heterotrophic and included both marine and freshwater strains. Data for a total of 98 strains of flexuous, gliding bacteria were subjected to computer analysis.

Although the accumulated information for the strains included in this study is somewhat restricted and represents a minimum degree of information suitable for Adansonian methods (Sokal \& Sneath, 1963), such an analysis should offer some insight into the relationships amongst the strains, thereby serving to focus attention on areas requiring additional study. Furthermore, the data, having been recorded and stored in the computer, are available for future reference and a more extended analysis with additional data for these or other strains of like bacteria. 


\section{METHODS}

In June 1965, the work on Adansonian analysis of the flexibacteria began when raw data for 55 strains of gliding bacteria were received from Dr R. A. Lewin's laboratory. Eighty-two features were coded for the 55 strains, and established procedures were used for a preliminary analysis by high-speed computer (Colwell \& Liston, 196I; Colwell, 1964). By the 'highest link' sorting (Sokal \& Sneath, 1963), three major clusters were noted, with all strains clustering at levels of $\geqslant 65 \% \mathrm{~S}$. Since the initial results were encouraging, subsequent computer analyses of 98 strains were done as more data became available. The strains used are listed in Table I. For information about sources, methods, etc., see Lewin (1962) and Lewin \& Lounsbery (1969). The features scored for the strains are given in Table 2.

Table I. List of strains included in the final computer study

\begin{tabular}{|c|c|c|c|c|c|}
\hline $\begin{array}{c}\text { Computer } \\
\text { identifica- } \\
\text { tion no. }\end{array}$ & $\begin{array}{l}\text { Laboratory } \\
\text { strain no. }\end{array}$ & $\begin{array}{c}\text { Computer } \\
\text { identifica- } \\
\text { tion no. }\end{array}$ & $\begin{array}{l}\text { Laboratory } \\
\text { strain no. }\end{array}$ & $\begin{array}{c}\text { Computer } \\
\text { identifica- } \\
\text { tion no. }\end{array}$ & $\begin{array}{c}\text { Laboratory } \\
\text { strain no. }\end{array}$ \\
\hline I & SIO-I & 34 & ENS & 67 & SNZ \\
\hline 2 & SIO-4 & 35 & H-43 & 68 & FLE \\
\hline 3 & si $0-7$ & 36 & HI-3 & 69 & MIC \\
\hline 4 & SIO-8 & 37 & HI-I 5 & 70 & WAR-5 \\
\hline 5 & SIO-9 & 38 & $\mathrm{II}-2$ & 71 & Dwo \\
\hline 6 & DAW-3 & 39 & JK-I I & 72 & PSY \\
\hline 7 & COP & 40 & $\mathrm{JC}-13$ & 73 & WH \\
\hline 8 & LIM-I & 41 & $N-3$ & 74 & PA-I \\
\hline 9 & $2 I$ & 42 & NN-I3 & 75 & PA-2 \\
\hline 10 & GOL-I 2 & 43 & $T V-2$ & 76 & PA-3 \\
\hline I I & DUB-4 & 44 & $\mathrm{~B}-\mathrm{A}$ & 77 & LJA \\
\hline 12 & B-9 & 45 & BON & 78 & LJB \\
\hline 13 & WFB-2I & 46 & $1-52$ & 79 & LJC \\
\hline 14 & B-I & 47 & $\mathrm{~L}-3$ & 80 & $s-23$ \\
\hline 15 & DD-I & 48 & $R=52$ & $8 I$ & $E-I$ \\
\hline I6 & GH-I & 49 & $R-53$ & 82 & E-2 \\
\hline 17 & GH-2 & 50 & $\mathrm{OL}-4$ & 83 & $M-I$ \\
\hline 18 & $\mathrm{HJ}-\mathrm{I}$ & $5 \mathrm{I}$ & $C R-63$ & 84 & $M-2$ \\
\hline 19 & $\mathrm{JL}-4$ & $5^{2}$ & $C R-8 I$ & 85 & ROB \\
\hline 20 & $\mathrm{NN}-3$ & 53 & CR-IO3 & 86 & SG-I \\
\hline 21 & $0-2$ & 54 & CR-IO4 & 87 & SG-2 \\
\hline 22 & Q-I & 55 & I 24 & 88 & DAW-I \\
\hline 23 & $Q-3$ & 56 & 131 & 89 & DAW-2 \\
\hline 24 & $Q Q-I$ & 57 & I $4 \mathrm{I}$ & 90 & DUB-2 \\
\hline 25 & QQ-3 & 58 & 155 & $9 \mathrm{I}$ & DUB-3 \\
\hline 26 & QQ-I I & 59 & $A-52$ & 92 & $A-I$ \\
\hline 27 & Ss-2 & 60 & BA-3 & 93 & $A-2$ \\
\hline 28 & ST-I & $6 I$ & $B A-23$ & 94 & $A-3$ \\
\hline 29 & $T-3$ & 62 & BA-24 & 95 & $\mathrm{JL}-\mathrm{I}$ \\
\hline 30 & $T-13$ & 63 & $\mathrm{VC}-2$ & 96 & BEG \\
\hline $3 I$ & $Y-I$ & 64 & $V-I$ & 97 & CR I 23 \\
\hline 32 & EE-I 3 & 65 & EGP & 98 & CR I 25 \\
\hline 33 & $E G=I 3$ & 66 & GEY & & \\
\hline
\end{tabular}

The laboratory data sheets were transcribed for keypunching, scoring ' 0 ' for a feature absent or negative, ' $I$ ' for a feature present or positive and ' 3 ' for a feature not tested or a test not applicable. Negative matches were not included in the computation of S (Sokal \& Sneath, 1963). The card file has been kept expansible in order to 
accommodate new data as received. The present matrix for the working computer programmes can accommodate 10,000 strains $\times 1000$ features.

During the course of the study a series of programmes was used. Programmes GTP-I to GTP-5 (GTP = Georgetown Taxonomy Programme) were developed for the IBM

Table 2. Coded features employed in the final computer analysis of the flexibacteria*

\begin{tabular}{|c|c|c|c|c|}
\hline $\begin{array}{l}\text { Computer } \\
\text { feature } \\
\text { code no. }\end{array}$ & Feature description & $\begin{array}{c}\text { Computer } \\
\text { feature } \\
\text { code no. }\end{array}$ & Feature des & scription \\
\hline I & $<10 \mu \mathrm{m}$. length & $3 \mathbf{I}$ & \multicolumn{2}{|l|}{ L-Arginine } \\
\hline 2 & I0-50 $\mu \mathrm{m}$. length & 32 & \multicolumn{2}{|l|}{ L-Aspargine } \\
\hline 3 & $>50 \mu \mathrm{m}$. length & 33 & \multicolumn{2}{|l|}{ L-Histidine } \\
\hline 4 & Helical & 34 & \multicolumn{2}{|l|}{ L-Glycine } \\
\hline $\begin{array}{l}4 \\
5\end{array}$ & Rhapidosomes observed & 35 & \multicolumn{2}{|l|}{ L-Isoleucine } \\
\hline 6 & Slight coiling & 36 & \multicolumn{2}{|l|}{ L-Leucine } \\
\hline 7 & Pigment I-red (flexixanthin) & 37 & \multicolumn{2}{|c|}{ L-Lysine $\quad$ requirement } \\
\hline 8 & Pigment II-pink & 38 & \multicolumn{2}{|c|}{ L-Methionine } \\
\hline 9 & Pigment III-orange (saproxanthin) & 39 & \multicolumn{2}{|l|}{ L-Phenylalanine } \\
\hline IO & Pigment IV-yellow (zeaxanthin) & 40 & \multicolumn{2}{|l|}{ L-Threonine } \\
\hline I I & Pigment V-yellow & $4 I$ & \multicolumn{2}{|l|}{ L-Tryptophane } \\
\hline 12 & Pigment VI--red & 42 & \multicolumn{2}{|l|}{ L-Valine } \\
\hline 13 & Cellulose digested & 43 & \multicolumn{2}{|c|}{ Vitamin $B_{1}$ required } \\
\hline 14 & Starch hydrolyzed & 44 & \multicolumn{2}{|c|}{ Vitamin $B_{12}$ required } \\
\hline 15 & Gelatin hydrolyzed & 45 & \multicolumn{2}{|c|}{ Other vitamin requirement } \\
\hline 16 & Agar digested & 46 & \multicolumn{2}{|c|}{ Freshwater } \\
\hline 17 & Catalase present & 47 & \multirow{2}{*}{\multicolumn{2}{|c|}{$\frac{1}{2} \times$ sea water Salinity }} \\
\hline 18 & Tyrosine 5 g./1.-growth & 48 & & Sea water tolerance \\
\hline 19 & Tyrosine $5 \mathrm{~g} . / 1$ - - ring & 49 & \multicolumn{2}{|l|}{$2 \times$ sea water } \\
\hline 20 & Tyrosine $5 \mathrm{~g} . / 1$-clearing & 50 & \multicolumn{2}{|l|}{$\left.35^{\circ}\right)$ Growth } \\
\hline $2 \mathrm{I}$ & $\mathrm{H}_{2} \mathrm{~S}$ produced & 51 & \multicolumn{2}{|l|}{$40^{\circ} \circ$ temperatures } \\
\hline 22 & 0.1 g./l. DOPA - growth & 52 & \multicolumn{2}{|l|}{ Tryptone } \\
\hline 23 & 0.1 g./I. DOPA-ring & 53 & \multicolumn{2}{|l|}{ Casamino acids } \\
\hline 24 & 0.1 g./1. DOPA-clearing & 54 & \multicolumn{2}{|c|}{$\mathrm{Na}$ glutamate I g./l. $\int_{\text {source }}^{\text {sotilized }}$} \\
\hline 25 & $0.001 \mathrm{~g} . / 1$. penicillin tolerated & 55 & \multicolumn{2}{|c|}{ Na nitrate $0.3 \mathrm{~g} . / 1$. utilized } \\
\hline 26 & $0.000 \mathrm{I}$ g./l. penicillin tolerated & 56 & \multicolumn{2}{|l|}{ Acetate $5 \mathrm{~g} .1 \mathrm{l}}$. \\
\hline 27 & $0.0000 \mathrm{I}$ g. $/ 1$. penicillin tolerated & 57 & \multicolumn{2}{|l|}{ Acetate I g./l. } \\
\hline 28 & $0.00000 \mathrm{r}$ g./l. penicillin tolerated & 58 & Lactate $5 \mathrm{~g} . / 1$. & \\
\hline 29 & Sodium lauryl sulphate-sensitive & 59 & Lactate I g./1. & \\
\hline 30 & Alginate degraded & 60 & Glycerol $5 \mathrm{~g} . / 1$ & \\
\hline & & $6 \mathrm{I}$ & Glycerol I g./l. & Carbon \\
\hline & & 62 & Glucose $5 \mathrm{~g} . / 1$ & source \\
\hline & & 63 & Glucose I g./l. & utilized \\
\hline & & 64 & Galactose 5 g./1. & \\
\hline & & 65 & Galactose I g./1. & \\
\hline & & 66 & Sucrose $5 \mathrm{~g} . / \mathrm{l}$. & \\
\hline & & 67 & Sucrose I g./l. & \\
\hline
\end{tabular}

* See Lewin \& Lounsbery (1969) for details of media, tests, etc.

I620 and the IBM $360 / 40$ computer systems from programmes written during the earlier work (Colwell \& Liston, I96I; Colwell, 1964). Essentially, these programmes provide a full S value matrix (GTP-I), a modified link sort and clustering at decrements of similarity values (GTP-2) (R. R. Colwell, to be published), feature frequency sort (GTP-3) (Colwell, 1964), median organism calculation (GTP-4) (Liston, Wiebe \& Colwell, 1963) and an S-value triangle chart (GTP-2-chart).

Since September 1967, programmes GTP-I to GTP-5 have been consolidated into 


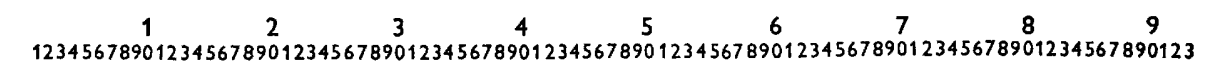

1
2

\begin{tabular}{l}
4 \\
5 \\
6 \\
7 \\
8 \\
\hline
\end{tabular}

$$
10
$$

10
11

12 逝:

14 渄:

17 16:

18
19
20 :

223 .

25 , 而期:

3.

33
34
35
36

$$
\begin{aligned}
& 36 \\
& 37 \\
& 38
\end{aligned}
$$$$
\begin{aligned}
& 38 \\
& 39 \\
& 40
\end{aligned}
$$$$
4
$$

41
42
43

44
45
46

46

48
49
50

50

52

5

5

57
58
59
60

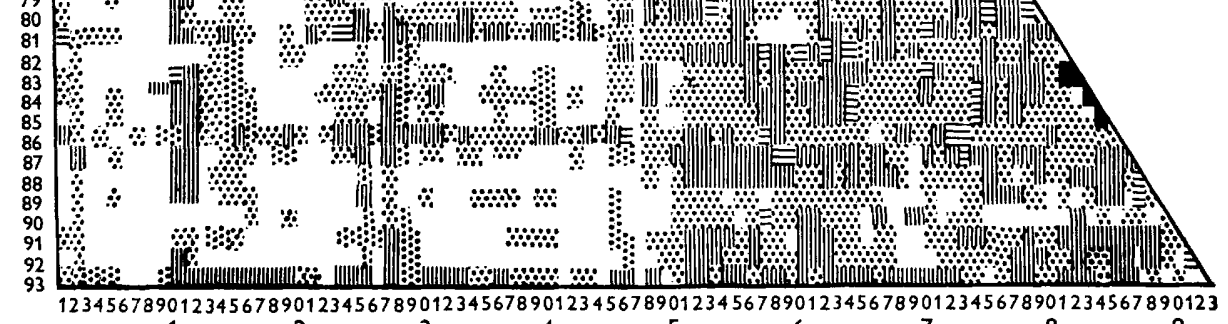

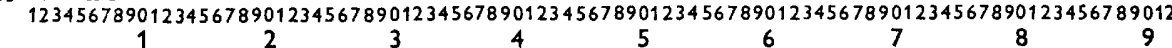

Fig. 2. Total S-value output for 93 strains of flexibacteria. 


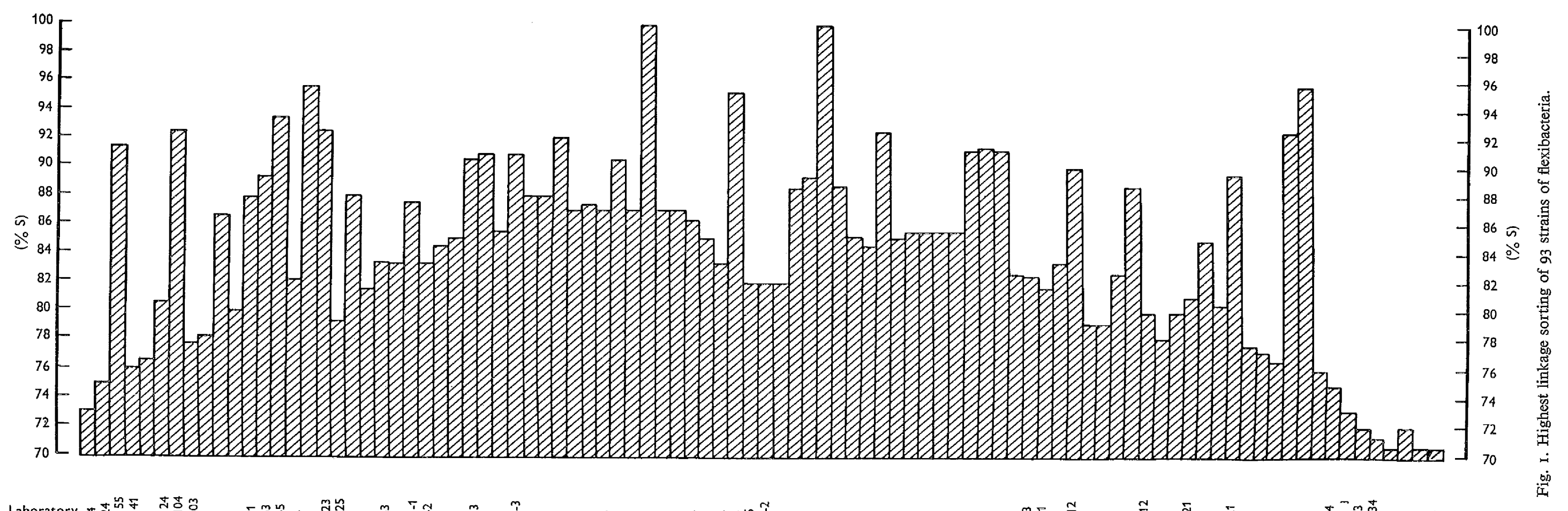

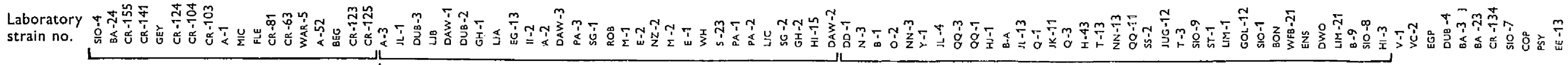


a master programme for the IBM Model 360/40 System. The IBM 360/40 System used in this study contains $13 \mathrm{I}, 000$ bytes of core storage, four disk drives and four magnetic tape units.

\section{RESULTS}

The sorted output from the computer an alysis of 93 strains is presented in Fig. I. On the basis of the data encoded for the strains, all grouped at $>70 \% \mathrm{~S}$ by the highest linkage sorting technique. A large cluster, A-3 to HI-3, and two subclusters, A-3 to DAW-2 and DD-I to HI-3, were obtained (see Fig. I). The full S-value matrix is given in Fig. 2, in which the corresponding strain numbers are 19 to 82 , 19 to 47 and 48 to 82 , respectively. A third and less homogeneous cluster, SIO 4 to CR-I 25 (I to I 8 in Fig. 2) was also indicated. In general, except for the more closely related clusters, highly similar in over-all features, the groupings which may be regarded as possible species are: BA-24, CR-I 55, CR-I4I ; GR-I 24, CR-IO4, CR-I03; CR-8I, CR-63, WAR-5, A-52, BEG, CR-I 23, CR-I25; A-3 to DAW-2 (see Fig. I) and N-3 to HI-3 (see Fig. I). From Fig. 2 no completely unequivocal separations into clearly unrelated, although certain internally homogeneous, groups were obvious.

The strains, arranged in order as in Fig. I and 2, approximate reasonably well the groupings on the basis of over-all DNA base compositions. For the most part, the features for strains from freshwater and marine habitats and for strains capable of cellulose digestion (Table 3) correlate with other group features; but they would not be suitable key characters in a monothetic taxonomy (Lockhart \& Hartman, 1963) since some variation in the frequency of occurrence was observed.

With the full complement of feature data for the flexibacteria strains, listed in Table 2, a final analysis was run, including the full data set (Lewin \& Lounsbery, 1969) received after completion of the initial analyses. From this analysis, the 90-, 80and 75-phenons (Sokal \& Sneath, 1963) and the final ordering of strains are given in Table 3. Of the 98 strains examined, 74 were grouped at degrees of similarity of $\geqslant 80 \%$. At $75 \% \mathrm{~S}$, strains $\mathrm{T}-\mathrm{I} 3 \mathrm{3}$ and $\mathrm{T}-3$ joined the major cluster and A-52 joined a group of unidentified strains; strains GEY, CR-IO3 and CR-IO4 joined BEG, CR-I 23 and CR-I25; and a new group appeared consisting of the two strains CR-I4I and CR-155. At 75-S, 90 of the 98 strains (Table I) were sorted into groups.

The 90-, 80- and 75-phenons approximate to the species groups of Lewin (I969).

\section{DISCUSSION}

A review of the present status of the taxonomy of gliding microbes was presented by Soriano \& Lewin (1965). There can be little doubt that major revisions of the flexibacteria are required. The strains selected by Lewin \& Lounsbery (I969) for study and included in the Adansonian analysis reported here represent a sampling of flexibacteria, from an analysis of which some suggestions for the taxonomy of these forms can be made. The results of Adansonian analyses, in general, indicate a relatively high over-all similarity among the strains studied, though with some distinguishable subgroupings. The lack of very marked group distinctions may be due to the small number of characters used in the study. The minimum standard error, for example, for the S-value calculations was about $\pm 6 \%$.

In comparing the taxonomic decisions of Lewin (1969) based on analysis by Fager 
Table 3. Selected data for strains included in the final analysis of the study

The ordering of the strains is as established by the computer sorting. Specific epithets and strain numbers correspond to the designations of Lewin (1969).

GC Habitat

Laboratory strain no.

COP

CR-I 3 I

SIO-8

A-I

$\left.\begin{array}{l}\text { CR-81*7 } \\ \text { CR-63 } \\ \text { WAR-5 } \\ \text { A-52 } \\ \text { V-I } \\ \text { VC-2 } \\ \text { EGP }\end{array}\right]$

HII-3

SIO-9

T-I3

SS-2

NN-I 3

Q-3

QQ-3

ST-I

H-4

ENS

HI-I 5

EE-I3

JK-II

QQ-I

GH-2

WFB-2I

B-9

DUB-4

NN-3

JL-4

SIO-7

LIM-I

TV-2

$\mathrm{N}-3$

HJ-I

GH-I

Q-I

QQ-I I

JL-I 3

EG-I3

BA-3

FLE

BA-24

PSY

DWO

BON

o-2
Nomenclature assigned by

Flexibacter aurantiacus var. copepodarum

Microscilla marina Saprospira toviformis

F. flexilis

$F$. flexilis

F. flexilis

F. flexilis

Microscilla aggregans

var. catalatica

$M$. sericea

$M$. tractuosa

Herpetosiphon nigricans

$M$. aggregans

$M$. aggregans

Flexithrix dorotheae

Cytophaga diffluens

var. aprica

M. tractuosa

C. lytica

$F$. sancti

$M$. tractuosa

$M$. tractuosa

M. tractuosa

$M$. aggregans

M. tractuosa

C. lytica

C. lytica

C. diffluens

var. aprica

C. diffuens

C. diffluens

var. aprica

$M$. sericea

$C$. diffluens

M. furvescens

$C$. diffluens

$M$. arenaria

$M$. tractuosa

C. diffluens var. carnea

$M$. aggregans

$M$. aggregans

M. tractuosa

$F$. sancti

F. flexilis var. pelliculosus

$F$. flexilis var. iolanthae

$F$. aurantiacus

$F$. aurantiacus

C. lytica

C. diffluens Lewin, 1969 content $\uparrow$ Pigment Cellulose (freshwater (moles \%) category digestion or marine)

$\begin{array}{llll}32 & \text { IV } & - & M\end{array}$

$\dot{42} \quad$ III $\quad \dot{ } \quad \dot{\mathrm{M}}$

38

43

4 I

40

42

III-a +

III - F

$\begin{array}{lll}\text { III } & - & \text { F } \\ \text { III } & - & \text { F }\end{array}$

III - $\quad$ F

- $\quad F$

- F

44

35

39

37
53

53
37

42

37

37

36

33

46

36

38

37

39

35

34

33

37

40

35

39

42

42
45

45
40
32

34

37

40

36

37

46

39

4 I

32

$3 I$

34

42
F/M

M

M

F/M

M

M

M

M

M

F/M

M

F/M

F/M

F/M

M

M

F/M

M

M

M

M

M

M

M

M

M

M

M

M

M

F

F

F

F/M

M 
Table 3 (cont.)

\begin{tabular}{|c|c|c|c|c|c|c|}
\hline \multicolumn{2}{|c|}{$\begin{array}{l}\text { Laboratory } \\
\text { strain no. }\end{array}$} & $\begin{array}{c}\text { Nomenclature assigned by } \\
\text { Lewin } 1969\end{array}$ & $\begin{array}{c}\text { GC } \\
\text { content } \dagger \\
(\text { moles } \%)\end{array}$ & $\begin{array}{l}\text { Pigment } \\
\text { category }\end{array}$ & $\begin{array}{l}\text { Cellulose } \\
\text { digestion }\end{array}$ & $\begin{array}{l}\text { Habitat } \\
\text { (freshwat } \\
\text { or marin }\end{array}$ \\
\hline DD-I & & C. diffluens (?) & 35 & III & + & $M$ \\
\hline B-I & & C. diffluens & 42 & III & + & $\mathbf{M}$ \\
\hline GOL-1 2 & & C. diffluens & $4 \mathrm{I}$ & III & + & $\mathbf{M}$ \\
\hline$Y-I$ & & C. diffluens & 4I & III & + & $\mathbf{M}$ \\
\hline SIO-I & & C. latercula & 34 & VI & + & $\mathbf{M}$ \\
\hline $\mathrm{T}-3$ & & H. persica & 53 & III & - & $\mathbf{M}$ \\
\hline GEY & & F. ruber & 37 & I & - & $\mathrm{F}$ \\
\hline BEG & 7 & S. thermalis & 37 & II & - & $\mathrm{F}$ \\
\hline CR-I 25 & & S. thermalis & 33 & II & - & $\mathbf{F}$ \\
\hline CR-I 23 & \rfloor & S. thermalis & 35 & II & - & $\mathrm{F}$ \\
\hline CR-IO3 & & $F$. giganteus & 33 & II & - & $\mathrm{F}$ \\
\hline CR-IO4 & & $F$. giganteus & 32 & II & - & $\mathbf{F}$ \\
\hline CR-124 & & $F$. giganteus & 31 & II & - & $\mathrm{F}$ \\
\hline SIO-4 & & F. litoralis & 31 & I & - & $\mathbf{M}$ \\
\hline II-2 & & H. cohaerens & 45 & III & - & $\mathbf{M}$ \\
\hline$A-2$ & & S. grandis & 46 & III & - & $\mathrm{F} / \mathrm{M}$ \\
\hline DUB-2 & & S. grandis & 47 & III & - & $\mathrm{M}$ \\
\hline DAW-I & & S. grandis & 48 & III & - & $\mathrm{M}$ \\
\hline LJA & & S. grandis & 47 & III & - & $\mathbf{M}$ \\
\hline LJB & & S. grandis & 48 & III & - & . \\
\hline WH & & S. grandis & 48 & III & - & $\mathbf{M}$ \\
\hline$s-23$ & & S. grandis & 48 & III & - & . \\
\hline E-I & & $S$. grandis & 46 & III & - & $\mathrm{M}$ \\
\hline PA-3 & & $S$. grandis & 46 & III & - & $\mathrm{M}$ \\
\hline ROB & & S. grandis & 47 & III & - & $\mathrm{M}$ \\
\hline SG-2 & & $S$. grandis & $\begin{array}{l}4 ! \\
48\end{array}$ & III & - & M \\
\hline$M-2$ & & $S$. grandis & 47 & III & - & $\mathbf{M}$ \\
\hline SG-I & & S. grandis & 47 & III & - & $\mathbf{M}$ \\
\hline M-I & & S. grandis & 47 & III & - & M \\
\hline $\mathrm{E}-2$ & & S. grandis & 48 & III & - & $\mathbf{M}$ \\
\hline DUB-3 & & S. grandis & 46 & III & - & $\mathbf{M}$ \\
\hline DAW-3 & & S. grandis & 48 & . & - & M \\
\hline PA-I & & S. grandis & 47 & III & - & $\mathbf{M}$ \\
\hline LJC & & S. grandis & 48 & III & - & . \\
\hline DAW-2 & & S. grandis & 47 & III & - & M \\
\hline PA 2 & & S. grandis & 46 & III & - & $\mathrm{M}$ \\
\hline JL I & & S. grandis & 47 & III & - & $\mathrm{F} / \mathrm{M}$ \\
\hline$A-3$ & & $S$. grandis & 46 & III & - & $\mathrm{F} / \mathrm{M}$ \\
\hline SNZ & & S. flammula & 48 & III & - & $\mathrm{F} / \mathrm{M}$ \\
\hline CR-1 55 & 7 & F. roseolus & 39 & I & - & $\mathrm{F} / \mathrm{M}$ \\
\hline$C R-141$ & $\mathrm{i}$ & $F$. roseolus & 34 & I & - & $\mathrm{F} / \mathrm{M}$ \\
\hline
\end{tabular}

(I969) with the Adansonian conclusions presented here, good correlations were observed in general. There are, however, disagreements on positioning of individual strains and in the selection of certain strains for elevation to generic rank, viz. Herpetosiphon species, Microscilla species and Flexithrix dorotheae.

The Saprospira grandis group of strains is clearly distinguishable from most of the other organisms examined; there appears to be no difficulty in identifying members of this group. Of the 24 strains so identified, I6 clustered at $\geqslant 90 \% \mathrm{~S}$ and all 24 at $\geqslant 80 \% \mathrm{~S}$. The DNA base composition range ( 46 to 48 moles $\% \mathrm{GC}$ over-all) is 
narrow and offers firm evidence for considering the strains as a homogeneous species. Other species named by Lewin (1969) were Flexibacter flexilis, Saprospira thermalis, and Flexibacter giganteus, which corresponded to groupings in this analysis. The Cytophaga and Flexibacter species appear to be related to Saprospira grandis through Saprospira thermalis. The strains COP, CR-I3I, SIO-8, A-I, HI-3, SIO-9, T-I3, T-3, GEY, CR-124, and II-2 did not cluster together or with other strains at degrees of similarity $>75 \%$. Two strains, CR-I 55 and CR-I 4I, classified as Flexibacter roseolus by Lewin, share a $75 \%$ degree of over-all similarity.

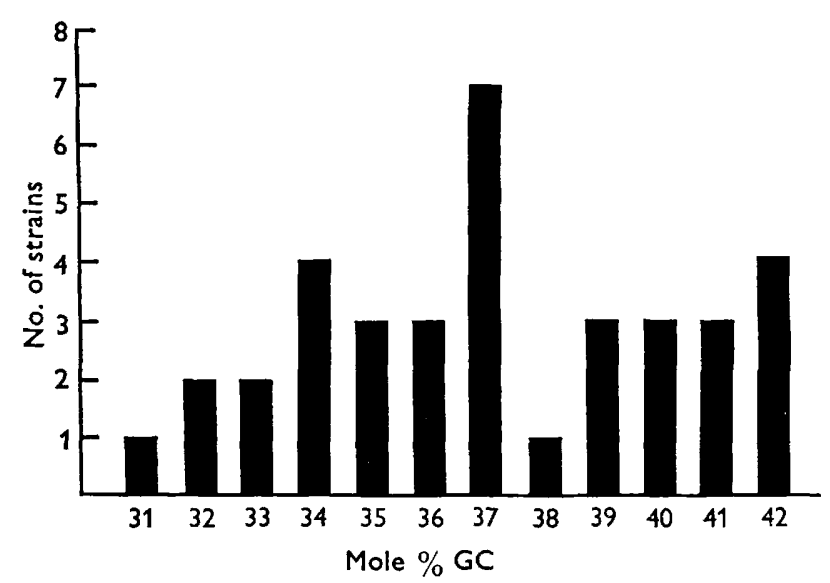

Fig. 3. Distribution of mole \% GC within the Cytophaga/Flexibacter/Microscilla 80-phenon.

The greatest difficulty in interpreting these data is associated with the strains NN- 3 to sIO-I, listed in Table 3, classified by Lewin (1969) as representing four genera, twelve species and four varieties. These strains share an over-all similarity of $\geqslant 80 \% \mathrm{~S}$ and represent a GC range of 3 I to $42 \%$. Thus it is difficult from these data to make 20 taxonomic distinctions.

Because a minimum of coded characteristics was available for the flexibacteria in cluded in this study, firm conclusions about the identification and classification of these strains must be avoided. Nevertheless, the following comments appear reasonable. There are apparently two major divisions of micro-organisms which show gliding, flexuous motility: the Saprospira grandis group and the Cytophaga/Flexibacter/Microscilla group. The characters used for describing these strains from nature appear to cross specific and probably, generic lines. The relatively separate and homogeneous clusters of strains identified as Saprospira grandis, Flexibacter flexilis, Saprospira thermalis, Flexibacter giganteus and Flexibacter roseolus by Lewin (1969) may be considered, as a working hypothesis, roughly equivalent to species. The large Cytophaga/Flexibacter/Microscilla aggregation, however, should be examined further for subclustering of strains. The range of DNA base compositions, 3 I to 42 moles $\%$ GC (see Fig. 3) would indicate, on purely molecular genetic grounds, at least three and perhaps more subgroupings. The high phenotypic similarities within the latter cluster suggest either a convergence of phenotype due to environmental selection, or, more likely, insufficient information at the present time for unequivocal identification of groups. 
The author gratefully acknowledges the excellent technical assistance of Mrs D. Lounsbery in preparing data for the computer and Mr R. D'Amico in writing the IBM $360 / 40$ computer programs. This work was supported in part by Research Grants GB 3363 and GB $6096 \times$ from the National Science Foundation.

\section{REFERENCES}

Colwell, R. R. (1964). A study of features used in the diagnosis of Pseudomonas aeruginosa. J. gen. Microbiol. 37, I8I.

Colwell, R. R. \& Liston, J. (I96I). Taxonomic relationships among the pseudomonads. J. Bact. 82, I.

FAGER, E. W. (1969). Recurrent group analysis in the classification of flexibacteria. J. gen. Microbiol. $58,179$.

Floodgate, G. D. \& Hayes, P. R. (1963). The Adansonian taxonomy of some yellow pigmented marine bacteria. J. gen. Microbiol. 30, 236.

HAYES, P. R. (1963). Studies on marine flavobacteria. J. gen. Microbiol. 30, I.

LEwIN, R. A (1962) Saprospira grandis Gross; and suggestions for reclassifying helical, apochlorotic, gliding organisms. Can. J. Microbiol 8, 555.

LEWIN, R. A. (1969). A classification of flexibacteria. J. gen. Microbiol. 58, I89.

LEwiN, R. A. \& Lounsbery, D. M. (I969). Isolation, cultivation and characterization of flexibacteria. J. gen. Microbiol. 58, 145.

Liston, J., Wiebe, W. \& ColWell, R R (1963). Quantitative approach to the study of bacterial species. J. Bact. 85, I06I.

LOCKHART, W. R. \& HARTMAN, P. A. (I963). Formation of monothetic groups in quantitative bacterial taxonomy. J. Bact. 85, 68

MANDEl, M. \& LeWIN, R. A. (1969). Deoxyribonucleic acid base composition of flexibacteria. J. gen. Microbiol. 58, I7I.

Sokal, R. R. \& SNeath, P. H. A. (1963). Principles of Numerical Taxonomy. San Francisco: W. H. Freeman.

Soriano, S. \& LeWIN, R. A. (1965). Gliding microbes: some taxonomic reconsiderations. Antonie van Leeuwenhoek 3I, 66.

\section{NOTE ADDED IN PROOF}

Examination of developing microcolonies produced microscopical evidence of general morphological agreement with the groupings obtained in this analysis. There were, however, two morphological types within the major phenon: a long cell form (I $2 \mu \mathrm{m}$.), relatively rapidly moving; and a short flexible $\operatorname{rod}(\mathrm{I} 2 \mu \mathrm{m}$.), rather sluggishly motile. The two morphological types respectively matched closely the Cytophagal Microscilla groupings as differentiated in the 'Comprehensive key to genera', sections $\mathrm{F} 23$ and F 24, in V. B. D. Skerman (1967), A Guide to the Identification of the Genera of Bacteria, 2nd ed. (Baltimore: Williams and Wilkins, $303 \mathrm{pp}$.). These observations were made by Professor V. B. D. Skerman during a visit to Georgetown University and the American Type Culture Collection, Washington, D.C., U.S.A. 